УДК.: $608.3+347.77$

DOI: 10.15587/2519-4852.2017.119091

\title{
ANALYSIS OF INNOVATIVE DEVELOPMENT STRATEGIES IN PHARMACY
}

\author{
() E. Litvinova, O. Posilkina
}

\begin{abstract}
Метою роботи є аналіз й узагальнення існуючих наукових підходів і механізмів щзодо формування стратегій інноваційного розвитку в фармації.

Матеріали та методи. Дослідження проводилися з використанням баз даних у мережі Інтернет: Українського патентного відомства, ДП «Державний експертний центр» МОЗ України, наукометричних баз даних. Використано ретроспективний та системно-аналітичний методи дослідження.

Результати. Виявлено, щуо найбільш перспективними напрямками інноваційного розвитку в фармації є: пошук пріоритетних терапевтичних напрямків, по яких має місце низький рівень задоволеності потреб охорони здоров'я в ефективних та безпечних лікарських засобах; розробка біосімілярів; препаратів на основі нанотехнологій; орфанних лікарських засобів; антиретровірусних препаратів. Проаналізовано та визначено перспективні стратегії пролонгації патентного захисту об'єктів інтелектуальної власності у фармації, щуо є невід'ємною умовою створення ефективних механізмів їх комериіалізації. Доведено актуальність використання механізмів державно-приватного партнерства в Україні для модернізаиї системи охорони здоров'я та фармації. Це сприятиме підвищенню інвестиційної привабливості фармацевтичної галузі для зарубіжних інвесторів і міжнародних організацій, і стимулювання інноваційних процесів.

Висновки. Раџіональний вибір інноваційної стратегї дозволяе фармацевтичним компаніям підтримувати та розширювати якість і ефективність інноваційної діяльності, виводити на внутрішні $i$ зовнішні фармацевтичні ринки нові оригінальні лікарські засоби в різних лікарських формах, доступні для широких верств населення
\end{abstract}

Ключові слова: патент, лікарський засіб, біосіміляр, орфанний препарат, антиретровірусний препарат, державно-приватне партнерство

\section{Introduction}

The vitality and prospects of the economic development of pharmacy in all countries of the world are largely determined by the scale, quality and level of scientific research and the level of technological processes that are being used. Today, the urgent task for the pharmaceutical industry of Ukraine is the transition to an innovative development model that will increase the quantity of modern, high-quality, efficient, safe and affordable medicines in the pharmaceutical market of Ukraine.

2. Formulation of the problem in a general way, the relevance of the theme and its connection with important scientific and practical issues

It should be noted that the trends of development of the modern domestic pharmaceutical industry are unsatisfactory from the point of view of national security. Taking into account the recommended list of medicines recommended by the WHO to redress the basic needs of developing countries, Ukraine does not have $32 \%$ of the required drugs. Currently, the pharmaceutical market of Ukraine is much larger than in previous years, the range of drugs represented by generic analogues, that take $94 \%$, and only $6 \%$ of the drugs are original. The segment of biologics and biosimilars in Ukraine is poorly developed, and by the end of 2015 (Q2) accumulates slightly more than 3\% of the drug market; moreover, import drugs do predominate. Imported medicines dominate the market in value terms (up to 60\%) $[1,2]$. This fact has a negative impact on the export-import balance of Ukraine, the development of the domestic pharmaceutical industry and national pharmaceutical science, which makes the country dependent on imports of pharmaceuticals, and endangers national security in the event of global or local emergencies.
3. Analysis of recent studies and publications in which a solution of the problem are described and to which the author refers

Various aspects of the innovation development of the pharmaceutical industry were studied in the works of many national researchers [1]. It should be noted that in recent years the attention to this problem has grown significantly and became relevant in pharmacy, as a result of the growth of competition in the domestic pharmaceutical market and the need to ensure an adequate level of competitiveness of Ukrainian pharmaceutical manufacturers, on the one hand, and the need to provide the domestic health care system with modern drugs, on the other.

4. The field of research considering the general problem, which is described in the article

In order to increase the efficiency of the pharmaceutical market entities and improve the medical provision of national health care, it is promising to study the strategies of innovative development of drug designers and manufacturers. The above will allow domestic pharmaceutical companies (PhC) to supply competitive market positions, improve their financial performance through more efficient use of patent assets, increase the competitiveness of innovative drugs, reduce the risks of drug designers at all stages of the life cycle, increase the attractiveness of innovative enterprises and projects for investors.

\section{Formulation of goals (tasks) of article}

The aim of the work is to analyze and generalize existing scientific approaches and mechanisms for the creation of strategies for innovation development in pharmacy. 


\section{Presentation of the main research material (methods and objects) with the justification of the results}

In the process of research were used general scientific methods of cognition, in particular, a systematic approach using the methods of retrospective and systemlogical analysis. The research was conducted using databases on the Internet: the Ukrainian Patent Office, "The State Expert Center" of the Ministry of Health of Ukraine, and scientometric databases.

Retrospective, logical, statistical and systemanalytical methods of research were used.

The creation of objects of innovation in pharmacy has significant differences in comparison with other branches: multi-stage innovation process, the presence of such specific stages, as biopharmaceutical, preclinical, clinical research; considerable length and high cost of development of original science absorbing drugs; relatively short duration of life cycle of most drugs; the need to provide affordable prices for them; severe competition both in the domestic and in the external pharmaceutical markets. It is also necessary to note the risk of discontinuation of work on the creation of a new drug in the case of its toxicity, insufficient clinical efficacy, unacceptable safety profile, lack of necessary investments and the effects of other negative factors. However, reproduction of the generic drug is also possible at low cost. Therefore, compensation of investments and time during the creation and production of original medicines provides precisely their patent protection. Thus, the pharmaceutical sector is one of the main users of the existing patent system.

The bases of intellectual property objects in the pharmacy consist, first of all, innovation in the field of the creation of new active pharmaceutical ingredients (APIs), manufactured pharmaceutical forms and technologies. The main factor in the success of any innovative organization in the market is constant innovation. Therefore, $\mathrm{PhCs}$, universities and academic institutes of the medical and pharmaceutical profile should have a portfolio of several innovative projects to develop original drugs that need to be replenished continuously. The presence of such a "portfolio" is not only a factor for improving the competitiveness of an innovative organization, but also a condition for its survival in a market environment.

The analysis revealed that in the national pharmacy, most of the presented priority therapeutic directions are developed in the field of treatment of the cardiovascular system, respiratory organs, tuberculosis, oncology, diabetes mellitus, pathology of mother and child, etc. You can also highlight the following priority directions in the creation of innovative medicines: new chemical compounds; synthesis of pharmacologically active metabolites or their isomers; the creation of new dosage forms with improved pharmacokinetic properties, which, thanks to maintaining the constant concentration of active substance in the blood, can reduce the frequency of drug administration; new means of drug delivery - inhalation, nasal, transdermal; biotechnology, bioengineering and nanotechnology, which today are among the most promising emerging research areas; the development of multicomponent drugs, each component of which is a drug with proven efficacy, safety and quality [3].
In the structure of intellectual resources in pharmacy, along with traditional elements, there are specific, requiring special methodological approaches to their management. Thus, biosimilars, nanoscience-based drugs, orphan drugs, antiretroviral drugs (ARVs) for the treatment of AIDS can be attributed to specific intellectual resources in pharmacy [4-8]. These drugs differ from the original drugs in their creation and production, in conducting clinical trials, in state registration, patenting, pharmaco-economic indicators. These are mainly high-tech, science absorbing and high-cost technologies, often with a narrow influence on the pathological process. All of this also implies high risks in the development, clinical trials of drugs, high cost of treatment, but ultimately the effect is most often prevail over risk. Due to the above, patents and the exclusivity of these drugs also have their own peculiarities that allow $\mathrm{PhCs}$ to prioritize certain areas of science, maintain control over a particular segment of the pharmaceutical market, and ensure substantial profits.

The most significant risk of commercialization of intellectual property in pharmacy is the loss of patent protection. The specifics of the pharmaceutical market are such that the pharmaceutical industry is faced with serious financial problems at the end of blockbuster patent protection. In order to minimize the risks of patent protection loss on key drugs, PhCs use a number of strategies to increase the shelf life of the API, thus extending the stage of commercialization of pharmaceutical innovation: patenting of new prolonged compositions of the known APIs, patenting of new methods for the introduction of known APIs, patenting of more efficient enantiomeric racemic drug, patenting of a new method for the use of known drugs, patenting a combination of two or more known AFIs, patenting a polymorphic form of drug (Table. 1) $[9,10]$.

The strategy of strengthening positions in a certain segment of the drug is actively used today by both foreign and domestic PhCs. An example is PAT Farmak (Ukraine), which produces a drug for urology - uronefron in 4 dosage forms, and thus strengthens its own position in the segment of drugs for the prevention and treatment of urolithiasis.

It should be noted that, as evidenced by world practice, creating favourable conditions for attracting investment resources for the development of domestic innovative medicines is possible only under the conditions of the development of state-private partnership aimed at the revival of the pharmaceutical, medical and biotechnology industries, which will significantly improve the situation with the provision of Ukrainian population with domestic innovative drugs [11].

From the point of view of the WHO Commission on Intellectual Property Rights, Innovation and Public Health, state-private partnership is an effective way to make good use of the opportunities of the state and private sectors to solve health problems, which cannot be properly resolved by any of the parties. Each side contributes: the state sector can provide support for research and take part in funding. And pharmaceutical companies can provide the process from the development of the drug to the assessment by the regulatory authorities (registration) and market entry. The complex mechanism for 
organizing the process of solving such problems often requires the pooling of resources and cooperation of stakeholders [11].

Implementation of the mechanisms of state-public partnership foresees a direct participation of the state in the development of the infrastructure of the region (industry) through direct budget financing, the creation and use of extrabudgetary funds, and the issue of loans; the establishment of incentives for manufactures aimed at implementing the concept of import substitution in Ukraine; various legal and consulting support for entrepre- neurs involved in the development of the pharmaceutical sector and provide not only the filling of the pharmaceutical market with the necessary drugs, but also the proper "medical security" of the country. Effective, but flexible state support should be foreseen for those domestic PhCs that take part in joint projects with foreign PhCs.

On the basis of the analysis of literary sources and views of various scientists, the main directions of innovation development in the pharmacy of domestic and foreign $\mathrm{PhCs}$ in the nearest perspective are systematized in Fig. 1.

Table 1

Examples of innovative strategies used by pharmaceutical companies to minimize the risks of patent protection loss on key drugs

\begin{tabular}{|c|c|c|c|}
\hline $\begin{array}{l}\text { Patent number in } \\
\text { Ukraine }\end{array}$ & $\begin{array}{l}\text { Date of receipt of } \\
\text { the patent }\end{array}$ & Patent holder & The name of the invention (utility model) \\
\hline \multicolumn{4}{|c|}{ New prolonged compositions of known substance } \\
\hline 112091 & 25.07.2016 & TOV «Pharma Start» & $\begin{array}{l}\text { Matrix tablet of quetiapine fumarate of prolonged } \\
\text { action and a method of its obtaining }\end{array}$ \\
\hline 111566 & 10.05.2016 & $\begin{array}{c}\text { PAT «Kievmedpreparat» } \\
\text { PAT «Galychpharm» }\end{array}$ & $\begin{array}{l}\text { Pharmaceutical composition of prolonged release } \\
\text { of morpholine [(5-methyl-1n-1,2,4-triazol-3-yl) } \\
\text { thio] acetate }\end{array}$ \\
\hline 110935 & 10.03 .2016 & Sanofi, France & Insulin prolonged release drug \\
\hline 97971 & 10.04.2012 & $\begin{array}{lr}\text { Boehringer } & \text { Ingelheim } \\
\text { International } & \text { GMBH, } \\
\text { Germany } & \end{array}$ & Nevirapine prolonged release drug \\
\hline 69447 & 25.04.2012 & $\begin{array}{l}\text { Zhebrovska F.I., Kostyuk } \\
\text { G.V., Gureyeva S.M. }\end{array}$ & Prolonged glyclazide matrix tablet \\
\hline \multicolumn{4}{|c|}{ New ways to administrate known substances } \\
\hline 110974 & 10.03.2016 & Euro-Celtic, Luxembourg & $\begin{array}{l}\text { Intranasal pharmaceutical dosage forms containing } \\
\text { naloxone }\end{array}$ \\
\hline 106935 & 10.05.2016 & TOV «Biopharma» & $\begin{array}{l}\text { Medicinal product for the prophylaxis and treat- } \\
\text { ment of diseases of the prostate gland in the form } \\
\text { of suppository "prostex" }\end{array}$ \\
\hline 108307 & 10.04.2015 & OOO NPK Tripharma, RF & $\begin{array}{l}\text { Pharmaceutical composition containing nalbu- } \\
\text { phine hydrochloride, its use for the treatment of } \\
\text { middle and high intensity pain syndrome and a } \\
\text { method for obtaining a pharmaceutical composi- } \\
\text { tion (variants) }\end{array}$ \\
\hline \multicolumn{4}{|c|}{ Patenting a more effective enantiomer of racemic drug } \\
\hline 105890 & 10.07.2014 & L'Institut Servier, France & $\begin{array}{l}\text { Method for the separation of enantiomers (3,4- } \\
\text { dimethoxybicyclo [4.2.0] octa-1,3,5-trien-7- } \\
\text { yl)nitrile and the application in the synthesis of } \\
\text { ivabradine }\end{array}$ \\
\hline \multicolumn{4}{|c|}{ Patenting a new way of use the known drugs } \\
\hline 85400 & 25.11.2013 & Zagoriy H.V. & $\begin{array}{l}\text { The use of a pharmaceutical composition of 1- } \\
\text { adamantylethyloxy-3-morpholino-2-propanol or } \\
\text { its pharmaceutically acceptable salts as a cerebro- } \\
\text { protective drug }\end{array}$ \\
\hline \multicolumn{4}{|c|}{ Patenting a combination of two or more known APIs } \\
\hline 109179 & 27.07.2015 & TOV Zdorovye & $\begin{array}{l}\text { Solid dosage form and method for its preparation } \\
\text { (thioctic acid, taurine, benfotiamine) }\end{array}$ \\
\hline 107083 & 25.11.2014 & Grindeks, Latvia & $\begin{array}{l}\text { Therapeutic combinations of nicotinic acid and } \\
\text { meldonium }\end{array}$ \\
\hline \multicolumn{4}{|c|}{ Patenting of polymorphic form of drugs } \\
\hline 111334 & 25.04.2016 & L'Institut Servier, France & $\begin{array}{l}\text { The delta-crystalline form of the perindroprile } \\
\text { arginine salt, the method for its preparation, and } \\
\text { the pharmaceutical composition containing it }\end{array}$ \\
\hline 100843 & 11.02 .2013 & KRKA, Slovenia & Polymorphic forms of ziprasidone sulfates \\
\hline 102816 & 27.08.2013 & L'Institut Servier, France & $\begin{array}{l}\text { Method of synthesis of crystalline form } \mathrm{v} \\
\text { agomelatin }\end{array}$ \\
\hline 93202 & 25.01.2011 & Egis, Hungary & $\begin{array}{l}\text { Polymorphic form of crystalline gemicalcium salt } \\
\text { of atorvastatin }\end{array}$ \\
\hline
\end{tabular}


Strategies for innovation development of pharmaceutical companies

\begin{tabular}{|c|c|c|c|c|}
\hline $\begin{array}{l}\text { Investing } \\
\text { in the } \\
\text { innovative } \\
\text { develop- } \\
\text { ments }\end{array}$ & $\begin{array}{l}\text { Search for } \\
\text { priority } \\
\text { therapeutic } \\
\text { directions }\end{array}$ & $\begin{array}{l}\text { Realization of } \\
\text { joint projects }\end{array}$ & $\begin{array}{c}\text { Prolongation } \\
\text { of patent } \\
\text { protection }\end{array}$ & $\begin{array}{l}\text { Strengthening of } \\
\text { positions in a } \\
\text { certain } \\
\text { pharmaco- } \\
\text { therapeutic group }\end{array}$ \\
\hline \multicolumn{3}{|c|}{$\begin{array}{l}\text { Foreign pharmaceutical } \\
\text { companies }\end{array}$} & \multicolumn{2}{|c|}{$\begin{array}{c}\text { National pharmaceutical } \\
\text { companies }\end{array}$} \\
\hline
\end{tabular}

Fig. 1. Generalization of strategies for innovation development, most actively used by foreign and domestic $\mathrm{PhCs}$

Thus, the rational choice of innovation strategy allows PhCs to maintain and expand the quality and effectiveness of innovation activities, actively bring to domestic and foreign pharmaceutical markets new original drugs in different dosage forms.

\section{Conclusions from the conducted research and prospects for further development of this field}

1 . The results of the carried out research show that the most promising directions of innovation development in pharmacy are: the search of priority therapeutic directions, where there is a low level of health care satisfaction, in effective and safe drugs; development of biosimilars; nanotechnology-based drugs; orphan drugs; antiretroviral drugs (ARVs) for the treatment of AIDS.

2 . The prospective strategies of prolongation of patent protection of intellectual property objects in phar- macy are analyzed and determined, which in their turn is an indispensable condition for the creation of effective mechanisms for their commercialization.

3. The urgency of using state-private partnership mechanisms in Ukraine to modernize the health care system and pharmacy has been proved. This will increase the investment attractiveness of the pharmaceutical industry for foreign investors and international organizations.

4. The conducted researches have shown that foreign PhCs most often use such strategies of innovative development as investing in innovative development; search of priority therapeutic directions, realization of joint projects financed by different sources; prolongation of patent protection, strengthening of positions in a certain segment of preparations. Domestic PhCs have not yet actively used most of these strategies and are in the stage of formation ones.

\section{References}

1. Farmatsiia XX stolittia: tendentsii ta perspektyvy [Text]: mat. VIII zizdu farm. Ukrainy. - Kharkiv: NFaU, 2016. - Vol. 1. - 458 p.

2. Dmitrik, E. Struktura rynka lekarstvennykh sredstv v razreze rynochnogo statusa [Electronic resource] / E. Dmitrik // Ezhenedel'nik Apteka. - 2015. - Vol. 1009 (38). - Available at: http://www.apteka.ua/article/346577

3. Shelepko, S. Zaglyadyvaya v budushhee: blokbastery i perspektivnye R\&D - novinki $2015 \mathrm{~g}$. [Electronic resource] / S. Shelepko // Ezhenedel'nik Apteka. - 2015. - Vol. 973 (2). - Available at: http://www.apteka.ua/article/320463

4. Shelepko, S. Biosimilyary na evropeyskom farmrynke: kakovy uspekhi i perspektivy? [Electronic resource] / S. Shelepko, E. Luk'yanchuk // Ezhenedel'nik Apteka. - 2016. - Vol. 976 (5). - Available at: http://www.apteka.ua/article/322521

5. Nanotekhnologii v farmatsii i meditsine [Text]: monografiya / A. F. Piminov (Ed.). - Kharkiv: Izd-vo Fakt, 2014. - 672 p.

6. Shelepko, S. Rynok orfannykh preparatov: kakie faktory obuslovlivayut rost? [Electronic resource] / S. Shelepko // Ezhenedel'nik Apteka. - 2017. - Vol. 1084 (13). - Available at: http://www.apteka.ua/article/404764

7. Antunes, A. Trends in Nanopharmaceutical Patents [Text] / A. Antunes, I. Fierro, R. Guerrante, F. Mendes, M. Alencar // International Journal of Molecular Sciences. - 2013. - Vol. 14, Issue 4. - P. 7016-7031. doi: 10.3390/ijms14047016

8. Giannuzzi, V. Orphan medicinal products in Europe and United States to cover needs of patients with rare diseases: an increased common effort is to be foreseen [Text] / V. Giannuzzi, R. Conte, A. Landi, S. A. Ottomano, D. Bonifazi, P. Baiardi et. al. // Orphanet Journal of Rare Diseases. - 2017. - Vol. 12, Issue 1. - P. 64-69. doi: 10.1186/s13023-017-0617-1

9. Clark, L. Patent term extensions: issues, challenges and implications for pharmaceuticals [Text] / L. Clark, D. Beadle // Pharmaceutical Patent Analyst. - 2012. - Vol. 1, Issue 4. - P. 427-435. doi: 10.4155/ppa.12.47

10. Cockburn, I. The importance of patents to innovation: updated cross-industry comparisons with biopharmaceuticals [Text] / I. Cockburn, G. Long // Expert Opinion on Therapeutic Patents. - 2015. - Vol. 25, Issue 7. - P. 739-742. doi: 10.1517/13543776. 2015.1040762

11. Dmitrik, E. Gosudarstvenno-chastnoe partnerstvo v sfere zdravookhraneniya. Mezhdunarodnyy opyt [Electronic resource] / E. Dmitrik // Ezhenedel'nik Apteka. - 2017. - Vol. 1104 (33). - Available at: http://www.apteka.ua/article/423444

Дата надходження рукопису 25.10.2017

Elena Litvinova, $\mathrm{PhD}$, Associate Professor, Department of Management and Economics of Enterprise, National University of Pharmacy, Pushkinska str., 53, Kharkiv, Ukraine, 61002

E-mail: hlitvinova@gmail.com

Olga Posilkina, Doctor of Pharmaceutical Sciences, Professor, Department of Management and Economics of Enterprise, National University of Pharmacy, Pushkinska str., 53, Kharkiv, Ukraine, 61002

E-mail: o.posilkina@gmail.com 